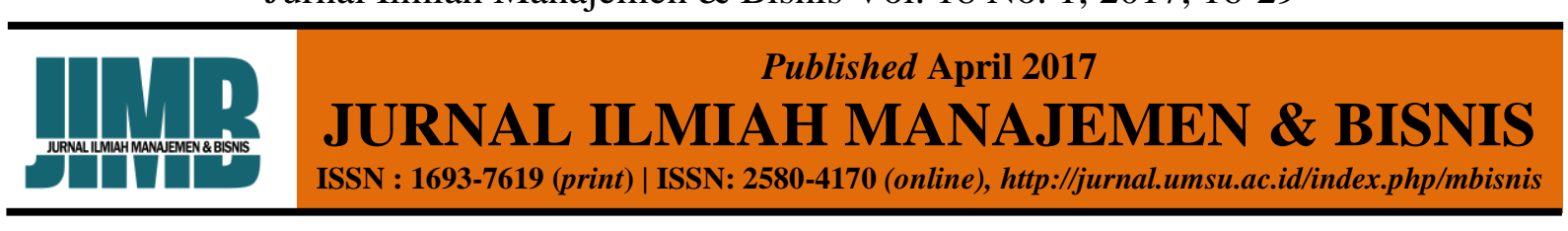

\title{
Analisis Penerapan Metode Discussion Dan Role Playing Untuk Meningkatkan Prestasi Belajar Mahasiswa Pada Mata Kuliah Manajemen Kinerja
}

\author{
Susi Handayani ${ }^{1{ }^{*}}$, Hasrudy Tanjung ${ }^{2)}$ \\ Fakultas Ekonomi Dan Bisnis Universitas Muhammadiyah Sumatera Utara \\ *Email: susihandayani@umsu.ac.id
}

\begin{abstract}
ABSTRAK
Penelitian ini ini bertujuan untuk menganalisis pengaruh penerapan metode discussion dan role playing di dalam kelas manajemen kinerja, apakah lebih lebih efektif dibandingkan dengan metode ceramah yang sebelumnya digunakan oleh kebanyakan pelajar. Hal ini disebabkan karena metode yang lama dinilai kurang efektif dan tidak mendapatkan hasil yang optimal. Secara visual mahasiswa cenderung kurang bersemangan dalam belajar, kurang ekspresif dan kurang terganli kemampuan inidividunya. Penelitian ini diharapkan dapat memberikan warna baru bagi mahasiswa dan pengajarnya, sehingga akan membuat mahasiswa menjadi lebih kreatif dan bersemangat dalam belajar sehingga prestasi belajar akan menjadi semakin baik. Penelitian ini juga akan membantu meningkatkan kemandirian, kepercayaan diri dan jiwa kompetitif dari mahasiswa karena metode yang diterapkan lebih interaktif, melibatkan keduabelah pihak yaitu mahasiswa dan dosennya serta kemampuan bekerja sama dalam kelompok sehingga jauh dari kesan monoton. Penelitian ini merupakan penelitian tindakan kelas, yang dirancang secara khusus dalam penerapannya dan disesuaikan dengan silabus dan satuan acara perkuliahan yang telah disepakati oleh pihak institusi. Hasil dari penelitian sudah seperti yang diharapkan walau belum maksimal, peningkatan prestasi mahasiswa sudah terlihat dengan hasil test yang dilakukan oleh peneliti. Prilaku mahasiswa juga terlihat ada perubahan, lebih percaya diri, kreatif, toleransi lebih baik, kooperatif dan lebih mandiri.
\end{abstract}

Kata Kunci: Discussion, role playing dan prestasi

\section{Analysis of Application of Discussion and Role Playing Methods to Improve Student Achievement on the Performance Management Lessons}

\begin{abstract}
This study aims to analyze the influence of the application of discussion and role playing methods in the performance management class, whether more effective than the lecture method previously used by most students. This is because the old method is considered less effective and does not get optimal results. Visually the students tend to be less immature in learning, less expressive and less terganli abilities inidividunya. This research is expected to provide new colors for students and teachers, so that will make students become more creative and passionate in learning so that learning achievement will become better. This research will also help to increase the selfreliance, self-confidence and competitive spirit of the students because the method is applied more interactively, involving both parties ie students and lecturers and the ability to work together in groups so far from monotonous impression. This research is a classroom action research, designed specifically in its application and adapted to the syllabus and lecture unit units agreed upon by the institution. The results of the study was as expected although not maximal, the increase in student achievement has been seen with the results of tests conducted by researchers. Student behavior is also seen there are changes, more confident, creative, better tolerance, cooperative and more independent.
\end{abstract}

Keywords: Discussion, role playing and achievement

How to cite:

Handayani, S., dan Tanjung, H. (2017). Analisis Penerapan Metode Discussion Dan Role Playing Untuk Meningkatkan Prestasi Belajar Mahasiswa Pada Mata Kuliah Manajemen Kinerja. Jurnal Ilmiah Manajemen \& Bisnis, 18(1), 16-29. 


\section{PENDAHULUAN}

Dalam upaya meningkatkan kualitas pendidikan maka perguruan tinggi yang merupakan salah satu tempat untuk memproses sumber daya manusia yang akan terjun di dunia kerja harus meningkatkan kualitas pembelajarannya. Oleh karena itu tersedianya sumberdaya yang baik dan memadai di perguruan tinggi merupakan persyaratan yang diperlukan, tetapi tidaklah mencukupi. Ketersediaan itu selalu masih harus dikaitkan dengan pengaturannya agar dapat menghasilkan kinerja yang lebih baik. Khusus mengenai sumberdaya terpenting, yaitu sumberdaya manusia, sikap, kepedulian dan kehendak mencapai kualitas merupakan persyaratan yang sama pentingnya dengan kemampuan ilmiah. Kurikulum yang baik merupakan dasar dari proses pembelajaran yang penting namun jika tidak ditunjang dengan metode pembelajaran yang tepat maka akan menjadi sia-sia. Sebagai salah satu wujud tanggung jawab atas kewajibannya, pendidik dituntut memilih metode pembelajaran yang paling akomodatif dan kondusif untuk mencapai sasaran dan filosofi pendidikan.

Manajemen Kinerja adalah salah satu mata kuliah konsentrasi yang dipilih sendiri oleh para mahasiswa sesuai dengan ketertarikan mereka. Mata kuliah konsentrasi kelak menjadi dasar ketika akan memilih topik penulisan tugas akhir atau skripsi. Manajemen Kinerja adalah mata kuliah aplikatif sebab teorinya sudah mereka dapatkan pada semester sebelumnya, dan sekarang mahasiswa belajar untuk menerapkannya dalam bentuk penyelesaian masalah. Mereka dituntut untuk peka dan responsive terhadap setiap permasalahan sehingga dapat menjawab atau memberikan solusi pada setiap masalah yang ada dalam manajemen kinerja.

Namun kenyataan yang ada, mahasiswa sering kesulitan dalam menyelesaian setiap soal yang diberikan. Jawaban yang diberikan tidak pernah memuaskan dan jauh dibawah harapan yang peneliti harapkan. Padahal seharusnya mereka tidak akan mengalami kesulitan karena teori sudah diberikan sebelumnya dan peneliti sudah mengulang kembali di dalam kelas. Bahkan sering peneliti berikan kesempatan pada mahasiswa untuk bertanya bila belum memahaminya. Hal ini tentu membuat peneliti kecewa dan prihatin, dan mencoba mencari penyebab mengapa mahasiswa tidak maksimal dalam proses pembelajaran. Padahal mata kuliah ini adalah mata kuliah pilihan dari mahasiswa itu sendiri.

Selama ini metode pembelajaran yang peneliti lakukan $90 \%$ adalah dalam bentuk ceramah (lecturing) dan sisanya adalah presentasi di kelas. Pada saat mengikuti kuliah atau mendengarkan ceramah, mahasiswa sebatas memahami sambil membuat catatan. Dosen menjadi pusat peran dalam pencapaian hasil pembelajaran dan seakan-akan menjadi satu-satunya sumber ilmu. Pola pembelajaran dosen aktif dengan mahasiswa pasif ini ternyata mempunyai efektivitas pembelajaran yang rendah. Pembelajaran yang diterapkan berfokus pada pemahaman materi saja dan mahasiswa tidak memiliki gambaran penerapan materi pada dunia bisnis. Karena metode pembelajaran belum dapat mengasah kemampuan analisis mahasiswa, kepekaan terhadap permasalahan, melatih pemecahan masalah serta kemampuan mengevaluasi permasalahan secara holistik.

Berdasarkan kenyataan ini peneliti menduga dalam mengajar ternyata metode ceramah tidak menghasilkan pembelajaran yang optimal. Peneliti merasa tidak puas dengan hasil yang dicapai oleh para mahasiswa baik dari sisi kualitas maupun kuantitas. Mahasiswa hanya menghapal materi tetapi sama sekali tidak memahami apalagi menjiwai mata kuliah yang diambilnya. Padahal mata kuliah ini adalah mata kuliah kosentrasi dimana mahasiswa memilih berdasarkan ketertarikan mereka 
sendiri. Artinya tidak ada unsur paksaan untuk memilih mata kuliah tersebut, sehingga logikanya dengan konsentrasi yang dipilih oleh mahasiswa seharusnya para mahasiswa bersungguh-sungguh dalam dalam belajar. Tapi pada kenyataannya yang terjadi justru sebaliknya banyak mahasiswa yang menunjukkan prestasi yang rendah.

Peneliti mencoba mencari kesalahan lain yang mungkin menjadi penyebab sehingga prestasi belajar mahasiswa tidak memuaskan, apakah hal ini disebabkan karena kesalahan dalam memilih konsentrasi atau lingkungan belajar selain pada metode pembelajaran yang selama ini peneliti terapkan. Kesalahan dalam memilih bisa saja terjadi karena belum tentu konsentrasi yang diambil para mahasiswa murni pilihan mereka sendiri. Ada beberapa factor yang menyebabkan mereka salah dalam memilih konsentrasi, yaitu ikut-ikutan teman, memandang mata kuliahnya tidak terlalu sulit dipelajari, peluang kerja yang besar bila memilih konsentrasi tententu atau ada hal-hal lain yang membuat mereka salah memilih konsentrasi. Tapi seharusnya hal ini tidak akan terjadi, karena sebelum peneliti memulai kelas, silabus sudah disosialisasikan kepada mahasiswa dan mereka diberi kesempatan untuk membatalkan pilihannya jika merasa tidak sesuai dengan jiwa mereka. Peneliti juga mensosialisasikan kontrak kuliah dan konsekuensinya jika mereka melanggarnya.

$$
\text { Lingkungan belajar bisa jadi }
$$
membuat mahasiswa tidak nyaman dalam belajar, misalnya terlalu penuh. Mahasiswa konsentrasi yang peneliti ampu memang luar biasa banyaknya, namun hal ini juga bukan alasan untuk membuat mereka tidak nyaman sebab kelas sudah didesain senyaman mungkin yaitu dengan membatasi jumlah dan memilih jam belajar sesuai dengan kebutuhan mahasiswa. Peneliti membuat beberapa opsi pilihan kelas, pagi hari, siang hari sampai sore hari. Mereka juga memilih teman yang akan menjadi teman sekelasnya, tentunya semua itu dengan kesepakatan yang sudah dibicarakan dengan mereka. Peneliti merasa yakin lingkungan belajar tidak cukup menjadi alasan untuk membuat mereka tidak antusias belajar.

Iidentifikasi yang peneliti lakukan terlihat beberapa gejala yang ditunjukkan oleh para masahiswa seperti hasil kuis yang tidak baik padahal materi baru disampaikan minggu lalu, mahasiswa terlihat tidak antusias dalam menanggapi pertanyaanpertanyaan yang disodorkan, mahasiswa tidak dapat menjawab pertanyaan secara jelas dan benar, padahal untuk semester 5 seharusnya mahasiswa sudah mulai belajar untuk berpikir sistematis dan yang lebih memprihatinkan didapati mahasiswa yang terkantuk-kantuk didalam kelas. Peneliti sudah mencoba membuat suasana kelas lebih hidup dengan melempar joke-joke yang dapat membuat mata mahasiswa tidak mengantuk atau peneliti memberikan ceramah denga cara yang lebih aktif dan atraktif seperti berjalan mengitari kelas, mendatangi para mahasiswa dan menyajikan warna dan gambar yang menarik pada slide yang ditayangkan. Namun hasilnya tetap tidak sesuai harapan.

\section{TINJAUAN PUSTAKA \\ Prestasi Belajar}

Prestasi adalah hasil yang sudah dicapai dari yang telah dilakukan, dikerjakan. Dalam prestasi ini diperoleh dari kegiatan belajar di sekolah atau perguruan tinggi yang bersifat kognitif dan biasanya ditentukan melalui pengukuran dan penelitian. Belajar penguasaan pengetahuan atau keterampilan yang dikembangkan melalui mata pelajaran, lazimnya ditunjukkan dengan nilai tes atau nilai angka yang diberikan oleh guru, hasil kerja yang dicapai oleh seorang karyawan dalam melaksanakan tugas yang dibebankan kepadanya (Pusat Bahasa Deppenas, 2007: 895). 
Dalam proses pendidikan prestasi dapat diartikan sebagai hasil dari proses belajar mengajar yakni, penguasaan, perubahan emosional, atau perubahan tingkah laku yang dapat diukur dengan tes tertentu (Abdullah, 2008). Prestasi belajar adalah hasil maksimum yang dicapai oleh seseorang setelah melakukan kegiatan belajar yang diberikan berdasarkan atas pengukuran tertentu (Ilyas, 2008).

Prestasi belajar adalah perubahan tingkah laku yang dianggap penting yang diharapkan dapat mencerminkan perubahan yang terjadi sebagai hasil belajar siswa, baik yang berdimensi cipta, dan rasa maupun yang berdimensi karsa (Syah M, 2006).

Jadi prestasi belajar adalah hasil belajar setelah mengikuti program pembelajaran yang dinyatakan dengan skor atau nilai. Pengukuran akan pencapaian prestasi belajar mahasiswa dalam pendidikan formal telah ditetapkan dalam jangka waktu yang bersifat caturwulan dan sering disebut dengan istilah mid semester (UTS) dan ujian akhir semester (UAS), tetapi dalam prestasi belajar diharapkan adalah peningkatan yang dilakukan dalam materi yang diajarkan. Untuk mengetahui prestasi belajar mahasiswa perlu diadakan suatu evaluasi yang bertujuan untuk mengetahui sejauh manakah proses belajar dan pembelajaran itu berlangsung secara efektif.

Maka untuk mengetahui prestasi belajar mahasiswa perlu diadakan suatu evaluasi yang bertujuan untuk mengetahui sejauh manakah proses belajar dan pembelajaran itu berlangsung secara efektif. Efektifitas proses belajar tersebut akan tampak pada kemampuan mahasiswa menguasai materi pelajaran.

1. Faktor-Faktor yang Mempengaruhi Prestasi Belajar

Menurut Slameto (2003) secara garis besarnya faktor-faktor yang dapat mempengaruhi prestasi belajar dapat dikelompokkan atas :

a. Faktor Internal: Faktor yang menyangkut seluruh pribadi termasuk kondisi fisik maupun mental atau psikis. Faktor internal ini sering disebut faktor instrinsik yang meliputi kondisi fisiologi dan kondisi psikologis yang mencakup minat, kecerdasan, bakat, motivasi, dan lainlain.

b. Faktor Eksternal

Faktor yang bersumber dari luar diri individu yang bersangkutan. Faktor ini sering disebut dengan faktor ekstrinsik yang meliputi segala sesuatu yang berasal dari luar diri individu yang dapat mempengaruhi prestasi belajarnya baik itu di lingkungan sosial maupun lingkungan lain (Djamara, 2008).

1) Faktor Lingkungan

Faktor lingkungan dapat dikelompokkan menjadi dua kelompok, yaitu:

a) Lingkungan Alami

Lingkungan alami seperti keadaan suhu, kelembaban udara berpengaruh terhadap proses dan hasil belajar. Belajar pada keadaan udara yang segar akan lebih baik hasilnya daripada belajar pada suhu udara yang lebih panas dan pengap.

b) Lingkungan Sosial

Lingkungan sosial, baik yang berwujud manusia dan representasinya (wakilnya), walaupun yang berwujud hal yang lain langsung berpengaruh terhadap proses dan hasil belajar. Seseorang yang sedang belajar memecahkan soal akan terganggu bila ada orang lain yang mondar-mandir di dekatnya atau keluar masuk kamar. Representasi manusia misalnya memotret, tulisan, dan rekaman suara juga 
berpengaruh terhadap hasil belajar.

2) Faktor Instrumental

Faktor-faktor instrumental adalah yang penggunaannya dirancang sesuai dengan hasil belajar yang diharapkan. Faktor-faktor ini diharapkan dapat berfungssebagai sarana untuk tercapainya tujuan yang telah dirancang. Faktorfaktor ini dapat berupa :

a) Perangkat keras /hard ware misalnya gedung, perlengkapan belajar, alatalat praktikum, dan sebagainya.

b) Perangkat lunak /soft ware seperti kurikulum, program, dan pedoman belajar lainnya.

\section{METODE DISKUSI (DISCUSSION)}

\section{Pengertian Metode Diskusi}

Diskusi adalah proses penglihatan dua atau lebih individu yang berinteraksi secara verbal dan saling berhadapan muka mengenai tujuan atau sasaran yang sudah tertentu melalui cara tukar menukar informasi, mempertahankan pendapat atau pemecahan masalah. Diskusi juga dapat diartikan sebagai suatu pertemuan ilmiah untuk bertukar pikiran mengenai suatu masalah.

Metode diskusi adalah suatu cara penyajian bahan pelajaran dimana guru memberi kesempatan kepada para siswa (kelompokkelompok siswa) untuk mengadakan perbincangan ilmiah guna mengumpulkan pendapat, membuat kesimpulan, atau menyusun berbagai alternatife pemecahan atas suatu masalah yang bisa berupa pernyataan atau pertanyaan yang bersifat problematik. Sebagai metode penyuluhan berkelompok, diskusi biasanya membahas satu topik yang menjadi perhatian umum di mana masing-masing anggota kelompok mempunyai kesempatan yang sama untuk bertanya atau memberikan pendapat.
Berdasarkan hal tersebut diskusi dapat dikatakan sebagai metode partisipatif.

\section{Tujuan Dan Manfaat Metode Diskusi}

1. Tujuan Metode Diskusi

a. Dengan diskusi siswa didorong menggunakan pengetahuan dan pengalamannya untuk memecahkan masalah, tanpa selalu bergantung pada pendapat orang lain (Siswa dilatih berpikir dan memecahkan masalah sendiri).

b. Siswa mampu menyatakan pendapatnya secara lisan, dalam hal ini siswa melatih diri untuk menyatakan pendapatnya sendiri secara lisan tentang suatu masalah bersama.

c. Diskusi memberi kemungkinan pada siswa untuk belajar berpartisipasi dalam pembicaraan untuk memecahkansuatu masalah bersama.

2. Manfaat Metode Diskusi

a. Untuk menimbulkan dan membina sikap dan prilaku demokratis siswa

b. Menumbuhkan dan mengembangkan sikap/cara berpikir logis, analitis dan kritis.

c. Memupuk kerjasama, toleransi dan rasa social .

d. Membina kemampuan mengemukakan pendapat dengan bahasa yang baik dan benar.

Hal-hal yang Harus Diperhatikan Dalam Menggunakan Metode Diskusi

a. Guru mengemukakan masalah yang akan didiskusikan dan memberikan pengarahan seperlunya mengenai caracara pemecahannya. Dapat pula pokok masalah yang akan didiskusikan itu ditentukan bersama-sama oleh guru dan siswa. Yang penting judul atau masalah yang akan didiskusikan harus dirumuskan sejelas-jelasnya agar dapat dipahami oleh peserta diskusi

b. Dengan pimpinan guru, para siswa membentuk kelompok-kelompok diskusi, memilih pimpinan diskusi ( 
ketua, sekretaris, moderator ) mengatur tempat duduk, ruangan, sarana dan sebagainya. Pimpinan diskusi sebaiknya berada ditangan siswa yang :

1) Lebih memahami masalah yang akan didiskusikan

2) "Berwibawa" dan disenangi oleh teman-temannya

3) Lancar berbicara

4) Dapat bertindak tegas dan demokratis

Peranan pimpinan diskusi antara lain:

1) Pimpinan diskusi sebagai pengatur lalu-lintas diskusi

Kewajiban untuk mengatur lalu-lintas berarti bahwa pimpinan diskusi berperan sebagai penemgah untuk mengatur jalan, arus dan arah pendapat dari orang agar tidak terjadi kesimpangsiuran, tabrakan ataupun pembicaraan yang tidak tertuju pada pokok diskusi.

2) Pimpinan diskusi sebagai dinding penangkis

Setiap kali pemimpin diskusi menerima pertanyaan-pertanyaan dari para peserta, ia harus segera menilai mana yang perlu dipantulkan kembali kepada kelompok, sehingga tidak terjadi tanya-jawab antara pemimpin diskusi dengan sejumlah kecil anggota diskusi saja.

3) Pimpinan diskusi sebagai penunjuk jalan

c. Para siswa berdiskusi dalam kelompoknya masing-masing, sedangkan guru berkeliling dari kelompok yang satu ke kelompok yang lain (kalau ada lebih dari satu kelompok) menjaga ketertiban, serta memberikan dorongan dan bantuan agar setiap anggota kelompok berpartisipasi aktif, dan agar diskusi berjalan lancar.

d. Jenis dan sifat pertanyaan yang layak untuk didiskusikan ialah yang :
1) Menarik minat anak didik yang sesuai dengan tarafnya.

2) Mempunyai kemungkinankemungkinan jawaban lebih dari sebuah yang dapat dipertahankan kebenarannya

3) Pada umumnya tidak menanyakan "manakah jawaban yang benar" tetapi lebih mengutamakan penalaran yang mempertimbangkan dan membandingkan. (Winarno Surakhmad,: 98-99).

Langkah-langkah metode diskusi

1) Persiapan perencanaan diskusi

a) Tujuan diskusi harus jelas, agar pengarahan diskusi lebih terjamin

b) Peserta diskusi harus memenuhi persyaratan tertentu, dan jumlahnya disesuaikan dengan sifat diskusi itu sendiri

c) Penentuan dan perumusan masalah yang akan didiskusikan harus jelas

d) Waktu dan tempat diskusi harus tepat, sehingga tidak akan berlarut larut.

2) Pelaksanaan diskusi

a) Membuat struktur kelompok

b) Membagi-bagi tugas dalam diskusi

c) Merangsang seluruh peserta untuk berpartisipasi

d) Mencatat ide-ide/ saran-saran yang penting

e) Menghargai setiap pendapat yang diajukan peserta

f) Menciptakan situakliemberikgn petunjukmenyenangkan

3) Tindak lanjut diskusi

a) Membuat kesimpulan/laporan diskusi

b) Membacakan kembali hasilnya untuk diadakan koreksi seperlunya

c) Membuat penilaian terhadap pelaksanaan diskusi tersebut untuk dijadikan bahan pertimbangan dan perbaikan pada diskusi-diskusi yang akan datang 
Beberapa kelebihan dalam penggunaan metode diskusi dalam kegiaatan pembelajaran adalah sebagai berikut:

a) Merangsang kreativitas anak-didik dalam bentuk ide,gagasan-prakarsa dan terobosan baru dalam pemecahan suatu masalah

b) Merangsang siswa untuk ikut mengemukakan pendapat sendiri, menyetujui atau menentang pendapat teman-temannya.

c) Memperluas wawasan

d) Membina untuk terbiasa musyawarah untuk mufakat dalam memecahkan suatu masalah.

e) Memberi kesempatan kepada siswa untuk memperoleh penjelasanpenjelasan dari berbagai sumber data.

f) Memberi kesempatan kepada siswa untuk menghayati pembaharuan suatu problem bersama-sama.

g) Membina suatu perasaan tanggung jawab mengenai suatu pendapat, kesimpulan, atau keputusan yang akan atau telah diambil.

h) Berdiskusi bukan hanya menuntut pengetahuan, siap dan kefasihan berbicara saja tetapi juga menuntut kemampuan berbicara secara sistematis dan logis.

i) Dengan mendengarkan semua keterangan yang dikemukakan oleh pembicara, pengetahuan dan pandangan siswa mengenai suatu problem akan bertambah luas.

j) Membina siswa untuk berpikir matangmatang sebelum berbicara.

Sedangkan kelemahan diskusi ketika digunakan dalam metode pembelajaran adalah sebagai berikut :

1. Tidak semua topik dapat dijadikan metode diskusi hanya hal-hal yang bersifat problematis saja yang dapat didiskusikan

2. Diskusi yang mendalam memerlukan banyak waktu
3. Sulit untuk menentukan batas luas atau kedalaman suatu uraian diskusi.

4. Biasanya tidak semua siswa berani menyatakan pendapat sehingga waktu akan terbuang karena menunggu siswa mengemukakan pendapat.

5. Pembicaraan dalam diskusi mungkin didominasi oleh siswa yang berani dan telah biasa berbicara. Siswa pemalu dan pendiam tidak akan menggunakan kesempatan untuk berbicara

6. Pembicaraan terkadang menyimpang, sehingga memerlukan waktu yang panjang

7. Memungkinkan timbulnya rasa permusuhan antarkelompok atau menganggap kelompoknya sendiri lebih pandai dan serba tahu daripada kelompok lain atau menganggap kelompok lain sebagai saingan, lebih rendah, remeh atau lebih bodoh.

8. Tidak dapat dipakai pada kelompok yang besar

9. Peserta mendapat informasiyang terbatas

10. Berhasil tidaknya diskusi banyak bergantung pada factor :
a. Kepandaian dan kelincahan pimpinan diskusi

b. Jelas tidaknya masalah dan tujuan yang dirumuskan

c. Partisipasi dari setiap anggota

d. Terciptanya situasi yang merangsang jalannya diskusi

e. Mengusahakan masalahnya supaya cukup problematic dan merangsang siswa berpikir.

\section{METODE PERMAINAN (ROLE PLAYING)}

Peranan adalah serangkaian perasaan, kata-kata, dan tindakan-tindakan terpola dan unik, yang telah merupakan kebiasaan seseorang dalam berhubungan dengan orang lain, termasuk berhubungan dengan situasi dan benda-benda (Wahab 2007: 109). Pada tahap yang paling sederhana bermain peran menghadapi permasalahan melalui kegiatan 
suatu masalah yang di telaah, ditindak dan kemudian didiskusikan (Sumantri dan Permana, 2001: 57). Menurut Sanjaya (2009: 161) bermain peran (role playing) adalah metode pembelajaran sebagai bagian dari simulasi yang diarahkan untuk mengkreasi peristiwa sejarah, mengkreasi peristiwa-peristiwa aktual, atau kejadiankejadian yang mungkin muncul pada masa mendatang. Lalu Sugihartono (2007: 83) menjelaskan bahwa role playing adalah metode pembelajaran melaluI pengembangan imajinasi dan penghayatan anak didik dengan cara anak didik memerankan suatu tokoh baik tokoh hidup atau tokoh mati. Sedangkan Zaini (2008: 98) mengemukakan pengertian bermain peran (role playing) dengan lebih luas yaitu bahwa role playing adalah suatu aktivitas pembelajaran terencana yang dirancang untuk mencapai tujuan-tujuan pendidikan secara spesifik. Esensi bermain peran menurut Sumantri dan Permana (2001: 57) adalah keterlibatan partisipan dan pengamat dalam situasi atau masalah nyata dan keinginan untuk mengatasinya.

Menurut Mulyasa dalam Muthoharoh (2009) terdapat empat asumsi yang mendasari pembelajaran bermain peran untuk mengembangkan perilaku dan nilainilai sosial yaitu:

1. Secara implisit bermain peran mendukung suatu situasi belajar berdasarkan pengalaman dengan menitikberatkan isi pelajaran pada situasi 'di sini pada saat ini'". Metode ini memungkinkan siswa menciptakan analogi mengenai situasi kehidupan nyata dalam bermain peran, sehingga siswa dapat menampilkan respon emosional sambil belajar dari respons orang lain.

2. Kedua, bermain peran memungkinkan para siswa untuk mengungkapkan perasaannya yang tidak dapat dikenal tanpa bercermin pada orang lain.

3. Metode bermain peran berasumsi bahwa emosi dan ide-ide dapat diangkat ke taraf sadar untuk kemudian ditingkatkan melalui proses kelompok. Dari kegiatan mengamati masalah yang sedang diperankan, para siswa dapat belajar dari pengalaman orang lain tentang cara memecahkan masalah yang pada gilirannya dapat dimanfaatkan untuk mengembangkan dirinya secara optimal. Oleh sebab itu, metode mengajar ini berusaha mengurangi peran guru yang teralu mendominasi pembelajaran dalam pendekatan tradisional. Metode bermain peran mendorong siswa untuk turut aktif dalam pemecahan masalah sambil menyimak secara seksama bagaimana orang lain berbicara mengenai masalah yang sedang dihadapi.

4. Metode bermain peran berasumsi bahwa proses psikologis yang tersembunyi, berupa sikap, nilai, perasaan dan sistem keyakinan, dapat diangkat ke taraf sadar melalui kombinasi pemeranan secara spontan. Dengan demikian para siswa dapat menguji sikap dan nilainya yang sesuai dengan orang lain, apakah sikap dan nilai yang dimilikinya perlu dipertahankan atau diubah.

Pengajar melibatkan peserta didik dalam bermain peran (role playing) karena berbagai alasan yang mendukung. Berbagai alasan yang mendukung tersebut antara lain:

1. Membandingkan dan mengkontraskan posisi-posisi yang diambil dalam pokok permasalahan.

2. Penerapkan pengetahuan pada pemecahan masalah.

3. Menjadikan problem yang abstrak menjadi konkret.

4. Melibatkan peserta didik dalam pembelajaran yang langsung dan eksperiensial.

5. Mendorong peserta didik memanipulasi pengetahuan dalam cara yang dinamik.

6. Mengembangkan pemahaman yang empatik (Zaini 2008: 102).

Role playing sebagai bagian dari metode simulasi menurut Hasibuan dan Moedjiono dalam Taniredja dkk. (2012: 4142) memiliki beberapa kelebihan yaitu: 
a. menyenangkan, sehingga siswa terdorong untuk berpartisipasi;

b. menggalakan guru untuk mengembangkan aktivitas simulasi;

c. memungkinkan eksperimen berlangsung tanpa memerlukan lingkungan yang sebenarnya;

d. memvisualisasikan hal-hal yang abstrak;

f. tidak membutuhkan ketrampilan komunikasi yang pelik;

g. memungkinkan terjadinya interaksi antar siswa;

h. menimbulkan respon yang positif dari siswa yag lamban, kurang cakap dan kurang motivasi;

i. melatih berpikir kritis karena siswa terlibat dalam analisa proses, kemajuan simulasi.

Banyak manfaat dari metode bermain peran menurut Ruminiati (2007: 5.5) antara lain:

(1) Sebagai sarana menggali perasaan siswa

(2) Untuk mengembangkan ketrampilan siswa dalam memecahkan masalahnya

(3) Untuk mendapatkan inspirasi dan pemahaman yang dapat mempengaruhi sikap, nilai dan persepsinya.

(4) Untuk mendalami isi mata pelajaran yang dipelajari

(5) Untuk bekal terjun ke masyarakat dimasa mendatang sehingga siswa dapat membawa diri menempatkan diri, menjaga dirinya sehingga sudah tidak asing lagi apabila dalam kehidupan bermasyarakat terjadi banyak siswa yang berbeda-beda.

Bermain peran (role playing) menurut Zaini (2008: 104-106) cenderung dibagi dalam tiga fase yang berbeda. Fase-fase tersebut yaitu:

(1) Perencanaan dan persiapan

Fase perencanaan dan persiapan ini mengandung pokok-pokok hal yang perlu dipertimbangkan guru antara lain: a. Mengenal peserta didik, b. Menentukan tujuan pembelajaran yang ingin dicapai,

c. Menentukan kapan pelaksanaan bermain peran (role playing),

d. Mempertimbangkan pendekatan umum bermain peran (role playing),

e. Mengidentifikasi skenario,

f. Menempatkan peran,

g. Guru memberlakukan diri sebagai pengamat,

h. Mempertimbangkan hambatan yang bersifat fisik,

i. Merencanakan waktu yang baik,

j. Dan mengumpulkan sumber informasi yang relevan.

(2) Interaksi

Fase kedua ini mempunyai langkahlangkah yaitu:

a. Membangun aturan dasar,

b. Mengeksplisitkan tujuan pembelajaran,

c. Membuat langkah-langkah yang jelas,

d. Mengurangi ketakutan tampil di depan publik,

e. Menggambarkan skenario atau situasi,

f. Mengalokasikan peran,

g. Memberi informasi yang cukup,

h. Menjelaskan peran mengajar dalam bermain peran (role playing),

i. Memulai bermain peran (role playing),

j. Menghentikan dan memulai kembali jika perlu,

k. Dan mengatur waktu.

(3) Refleksi dan Evaluasi

Refleksi dan evaluasi dilakukan oleh guru bersama dengan peserta didik agar penilaian kriteria terbuka.

Ada lima prinsip reaksi penting pada metode role playing menurut Sumantri dan Permana (2001: 59) yaitu: pertama, guru harus menerima respon dan saran siswa, terutama mengenai opini dan perasaannya, dalam sikap yang tidak mengevaluasi. Kedua, guru harus merespon sedemikian 
rupa untuk membantu siswa menjajagi berbagai segi situasi masalah. Ketiga, dengan melakukan refleksi, merumuskan kembali dan merangkum respon, guru meningkatkan kesadaran siswa mengenai pandangan dan perasaannya. Keempat, guru harus menekankan bahwa terdapat berbagai cara main yang berbeda untuk suatu peran dengan berbagai hasil yang berbeda. Kelima, terdapat beberapa alternatif pemecahan masalah. Penting untuk diperhatikan akibat-akibat daripada solusi itu.

Kelemahan metode bermain peran menurut Wahab (2007) yaitu: (1) jika siswa tidak dipersiapkan dengan baik ada kemungkinan tidak akan melakukan secara bersungguh-sungguh; (2) bermain peran mungkin tidak akan berjalan dengan baik jika suasana kelas tidak mendukung; (3) bermain peran tidak selamanya menuju pada arah yang diharapkan seseorang yang memainkannya; (4) siswa sering mengalami kesulitan untuk memerankan peran secara baik khususnya jika mereka tidak diarahkan atau tidak ditugasi dengan baik; (5) bermain memakan waktu yang banyak; (6) untuk berjalan baiknya sebuah bermain peran, diperlukan kelompok yang sensitif, imajinatif, terbuka, saling mengenal sehingga dapat bekerjasama dengan baik.

\section{METODE}

\section{Rencana Tindakan}

Pendekatan penelitian adalah tindakan kelas, yang bermaksud melakukan pengamatan terhadap proses dan hasil penerapan metode pembelajaran discussion dan role playing dalam mata kuliah manajemen Kinerja, apakah mampu meningkatkan prestasi belajar mahasiswa. Rencana tindakan yang akan dilakukan peneliti adalah:

1. Perencanaan. melakukan perencanaan kegiatan belajar mengajar yang akan dilakukan dengan merancang bentuk tugas dan metode yang dapat digunakan, mempersiapkan silabus, rencana pelaksanaan pembelajaran, hand out, lembar kerja mahasiswa, angket, lembar observasi pelaksanaan pembelajaran metode diskusi kelompok dan bermain peran.

2. Tindakan, melakukan pembelajaran dengan menggunakan model dan metode yang telah dirancang, di mana pembelajaran berpusat pada mahasiswa, sehingga mereka turut aktif dalam kelas. Untuk lebih mengoptimalkan dan mendapatkan hasil yang meyakinkan Peneliti menggunakan 2 kelas yaitu kelas A dimana kelas tersebut hanya menggunakan metode ceramah saja dan kelas B dimana kelas menggunakan metode diskusi dan bermain peran. Kelas-kelas tersebut akan dilihat keefektifannya, artinya kelas mana yang lebih antusias dalam belajar. Dan kelas mana yang akan memperoleh skor tertinggi untuk hasil tes yang akan dilakukan oleh peneliti. Peneliti membagi dalam 2 tahap, tahap 1 adalah ketika kelas belum menggunakan metode discussion dan role playing, kemudian tahap 2 adalah ketika kelas yang direncanakan sudah menggunakan metode tersebut.

\section{Teknik Pengumpulan Data}

Pengumpulan data dilakukan dengan 4 cara yaitu:

a. Observasi, yaitu pengamatan langsung pada obyek penelitian secara rutin ketika dalam proses pembelajaran dengan metode discussion dan role playing. Observasi ini membandingkan kelas A dan kelas B meliputi aktivitas mahasiswa ketika didalam kelas. Bagaimana keaktifan mereka dalam mengikut materi kuliah perminggunya.

b. Test/evaluasi yaitu membandingkan hasil prestasi belajar kelas yang menggunakan metode ceramah dengan kelas yang menggunakan metode discussion dan role playing

c. Angket atau kuisioner hanya diberikan 
pada kelas yang menggunakan metode discussion dan role playing untuk melihat antusias dan perasaan yang dialami oleh mereka di dalam kelas. Untuk kelas A peneliti tidak memberikan karena kelas A hanya sebagai kelas pembanding saja

d. Dokumentasi yang digunakan dalam penelitian ini yaitu silabus, rencana pelaksanaan pembelajaran, daftar nilai mahasiswa, daftar kelompok dan foto selama proses pembelajaran

\section{Teknik Analisis Data}

Data yang dikumpulkan akan dianalisis dengan analisis kualitatif untuk mendeskripsikan hasil observasi terhadap penerapan pembelajaran dengan metode discussion dan role playing dibandingkan dengan kelas yang tidak menggunakan metode ini. Kemudian melihat respon dari mahasiswa kelas B yang mengisi angket.

\section{HASIL DAN PEMBAHASAN}

\section{Hasil Penelitian}

\section{Tindakan Kelas}

Sesuai dengan pendekatan penelitian yaitu tindakan kelas, maka peneliti membuat kegiatan didalam kelas sesuai dengan rencana yang telah dipersiapkan sebelumnya. Menetapkan materi sesuai dengan Satua Acara Perkuliahan dan Garisgaris Besar Pokok Perkuliahan yang telah dibuat oleh tim, membuat instrumen untuk mengetahui antusiasme mahasiswa dalam belajar dengan menggunakan metode yang berbeda dengan sebelumnya yaitu metode diskusi (discussion) dan bemain peran (role playing). Kemudian peneliti juga membuat soal-soal tes yang akan dipergunakan untuk melihat kemajuan hasil penerapan metode yang telah dirancang. Untuk melihat tingkat efektifitas penerapan metode ini, peneliti membagi 2 kelompok yaitu satu kelas (A) dengan menggunakan metode ceramah, dan satu kelas (B) meggunakan metode diskusi dan bermain peran. Masing-masing kelas mendapatkan materi yang sama hanya dengan metode belajar yang berbeda. Dari hasil pengamatan langsung (observasi) yang dilakukan oleh peneliti selama 14 minggu terlihat hasil yang berbeda antara kelas A dan B.

Dari hasil pengamatan menunjukkan antusiasme mahasiswa kurang baik, terlihat hanya 3 orang yang aktif bertanya, mereka lebih suka menulis atau mendengarkan saja.

Dari hasil diatas menunjukkan antusiasme mahasiswa lebih tinggi, 24 orang atau $66 \%$ mahasiswa dikelas tersebut aktif bertanya. Cukup idealnya karena lebih dari $50 \%$ aktif bertanya. Dan dari pengamatan penulis mahasiswa yang aktif menulis lebih rendah, artinya mereka rata-rata memiliki ketertarikan untuk memahami materi sehingga lebih suka untuk bertanya langsung. Sedangkan yang pasif, hanya mendengar saja tidak lebih dari 2 orang atau $5,5 \%$.

\section{Penerapan Metode Diskusi dan bermain peran}

Untuk kelas B yang menggunakan metode discussion dan role playing peneliti menyiapkan silabus yang sesuai dengan Satuan Acara Perkuliahan namun dengan rancangan yang berbeda artinya disesuaikan dengan metode yang akan digunakan. Kelas B dibagi dalam kelompok yang masingmasing kelompok terdiri dari 6 orang. Dimana kelompok-kelompok ini akan membahas materi yang telah ditentukan dan masing-masing anggota akan mendapatkan peran yang berbeda-beda. Pada minggu yang sama peneliti melakukan tes dengan materi yang sama pada kedua kelas yaitu kelas A dan B, ada 3 tes/evaluasi yang dilakukan didalam kelas dengan pengawasan lansung dari tim peneliti.

Tes atau evaluasi yang pertama 
diberikan minggu ke 4 saat kedua kelas A dan B masih menggunakan metode ceramah. Dan hasilnya menunjukkan bahwa tes atau evaluasi yang lakukan oleh peneliti menunjukkan hasil yang sama sekali tidak memuaskan. Hasil yang kurang baik masih menunjukkan angka tertinggi pada kelas A maupun B. Untuk sementara disimpulkan bahwa mahasiswa masih belum dapat menyerap materi yang diberikan dengan baik.

Pada minggu ke 7 dilakukan tes atau evaluasi yang kedua, dimana kelas B sudah diterapkan metode discussion dan role playing sementara kelas A tetap dengan metode ceramah. Namun menunjukkan nilai yang kurang memuaskan, tidak ada mahasiswa yang mencapai nilai tertinggi, kebanyakan terpusat pada nilai kurang baik serta masih ada beberapa mahasiswa yang mendapatkan nilai kurang. Hal ini menandakan penyerapan materi masih kurang.

Sementara pada kelas B mahasiswa yang mendapatkan nilai tertinggi sudah ada, walau jumlahnya tidak banyak hanya 2 orang atau berkisar 5,5\%. Nilai mahasiswa terpusat pada tingkat yang baik yaitu 15 orang atau $41,6 \%$ dan yang mendapat nilai kurang hanya 1 orang atau $2,7 \%$. Hal ini menunjukkan materi yang diberikan sudah dapat diserap dengan baik walaupun belum maksimal, kemungkinan masih ada mahasiswa yang belum terbiasa dengan metode ini.

Pada minggu ke empat belas peneliti melakukan tes atau evaluasi lagi, sebagai evaluasi terakhir. Hasil tes untuk mahasiswa kelas A menunjukkan adanya peningkatan nilai dari mahasiswa, sudah ada yang mendapatkan nilai 80 namun tidak ada yang mendapatkan nilai tertinggi. Bahkan masih ada mahasiswa yang mendapatkan nilai cukup saja.

Hasil evaluasi terakhir untuk mahasiswa kelas B sudah menunjukkan kenaikan yang cukup signifikan, mahasiswa yang mendapatkan nilai tertinggi sudah meningkat. Mahasiswa kelihatannya sudah mulai beradaptasi dengan metode yang baru dan dapat menyerap materi dengan baik. Walaupun masih ada 1 orang mahasiswa menunjukkan nilai kurang baik.

Pada tahapan akhir siklus kedua ini untuk melihat respon mahasiswa terhadap metode pembelajaran ini maka disebar angket kepada mahasiswa, Angket respon mahasiswa terdiri dari 20 butir pertanyaan, penskoran angket adalah 4 untuk jawaban sangat setuju, 3 untuk jawaban setuju, 2 untuk jawaban tidak setuju, dan 1 untuk jawaban sangat tidak setuju.

Untuk jumlah skor hasil pengumpulan data diperoleh hasil sebesar 2411, sedangkan jumlah skor bila setiap butir skor mendapat nilai tertinggi diperoleh nilai sebesar 2880 , maka persentasi respon mahasiswa terhadap metode pembelajaran ini adalah sebesar 83,7 \% artinya respon mahasiswa terhadap metode pembelajaran ini sangat tinggi.

\section{Pembahasan}

Metode discussion dan role playing nampak masih asing di kalangan mahasiswa Fakultas Ekonomi UMSU, hal ini terlihat pada saat peneliti mulai mensosialisasikan metode ini pada awal kuliah. Beberapa mahasiswa memperlihatkan reaksi terkejut, menarik diri, dan mencoba untuk tidak ikut aktif dalam kegiatan dikelas. Ketika peneliti mulai membagi kelompok dalam kelas, mahasiswa agak sulit keluar dari zona amannya, dapat terlihat ketika mereka memohon untuk tetap dapat bersama teman dekat atau teman akrabnya. Tapi peneliti tetap bersikeras untuk menarik mereka dari zona aman mereka, akhirnya mereka harus terpisah dari teman-teman dekatnya. Dengan memasukkan mereka dalam kelompok yang asing diharapkan dapat meningkatkan sensitivitas mahasiswa terhadap lingkungan barunya, belajar untuk beradaptasi dan bekerja sama dengan lingkungan yang baru 
serta membentuk kemandirian. Masalah masih tetap ada ketika peneliti mengajak mahasiswa bermain peran (role playing), sikap minder, malu-malu dan tidak percaya diri sangat kelihatan dari mereka, mereka menolak dengan alasan bukan artis. Padahal tujuan menerapkan metode role playing adalah membuat mereka menghayati pekerjaan sesuai dengan perannya, bukan berakting seperti layaknya artis. Ketika mahasiswa berperan sebagai seorang direktur Produksi, maka otomatis dia harus mampu mendiskripsikan pekerjaannya dan ketika menghadapi masalah mereka juga tahu apa kewenangannya sehingga dapat mengambil keputusan. Metode yang mulamula dianggap aneh dan asing perlahanlahan mulai dapat diterima oleh mereka. Hal ini dapat dilihat dari keaktifan mereka didalam kelas, mahasiswa yang ada di kelas B terlihat lebih aktif dibadingkan mahasiswa yang ada di kelas A. Mereka terlihat sudah aktif bertanya, berlomba-lomba untuk menunjukkan kemampuan dan berdebat serta lebih percaya diri bila berbicara didepan kelas ketika presentasi. Hasil tes juga menunjukkan peningkatan yang cukup baik.

\section{SIMPULAN}

Berdasarkan pada hasil penelitian dapat ditarik kesimpulan bahwa penerapan metode discussion and role playing secara nyata dapat meningkatkan prestasi belajar mahasiswa dalam pembelajaran mata kuliah Manajemen Kinerja pada konsentrasi Manajemen Sumber Daya Manusia di Fakultas Ekonomi jurusan Manajemen Universitas Muhammadiyah Sumatera Utara. Kelas yang menggunakan metode discussion dan role playing memperoleh nilai yang lebih tinggi dan cenderung meningkat dibandingkan dengan kelas yang hanya menggunakan metode ceramah. Hal ini dapat dilihat dari kenaikan nilai yang diperoleh dalam tes yang diberikan selama masa pembelajaran. Dampak positif dari metode discussion and role playing adalah meningkatkan psikologis mahasiswa seperti keberanian mahasiswa dalam berekspesi dan menggali kemampuan dirinya, dari minder menjadi lebih percaya diri serta meningkatnya kemandirian. Berdasarkan kesimpulan dan dampak dari hasil penelitian ini, disarankan bahwa penerapan metode discussion and role playing sebaiknya dapat dikembangkan pada mata kuliah-mata kuliah yang lain mengingat dampak dari metode ini dapat meningkatkan prestasi belajar mahasiswa, agar pengajar mempersiapan metode ini dengan lebih terarah dan terstruktur sehingga tidak ada lagi mahasiswa yang mendapatkan nilai rendah lagi, masih banyaknya kelemahankelemahan yang peneliti rasakan pada saat menerapkan metode ini terutama dalam persiapan mental dan psikologis dosen dan mahasiswa. Untuk itu diharapkan dengan persiapan yang lebih baik niscaya akan mengoptimalkan hasil.

\section{REFERENSI}

Abdul Azis Wahab 2007. Metode dan Model-Model Mengajar: Ilmu Pengetahuan Sosial (IPS). Bandung: Alfabeta.

Mulyasa, 2007. Kurikulum Tingkat Satuan Pendidikan. Bandung: Rosdakarya

Hafiz Muthoharoh (2009). Model Bermain Peran (Role Playing) dalam Pembelajaran Partisipatif Online

Slameta (2003). Belajar dan Faktor-faktor Yang Mempengaruhinya. Jakarta: Rineka Cipta.

Suharsimi Arikunto 2012. Dasar-Dasar Evaluasi Pendidikan. Jakarta: Bumi Aksara.

Suharsimi Arikunto, Suhardjono dan Supardi, 2012, Penelitian Tindakan Kelas, PT.Bumi Aksara Jakarta.

Sumantri, Mulyani dan Johar Permana. 2001. Strategi Belajar Mengajar Bandung: CV. Maulana.

Sumantri, Mulyani dan Nana Syaodih. 2009. Perkembangan Peserta didik. Jakarta: Universitas Terbuka. 
Taniredja, Tukiran, dkk.. 2012. ModelModel Pembelajaran Inovatif. Bandung: Alfabeta.

Wina Sanjaya. 2006. Strategi Pembelajaran Berorientasi Standar Proses Pendidikan. Jakarta: Kencana.

Wina Sanjaya, 2008. Kurikulum dan Pembelajaran. Jakarta: Kencana Media Group

Zaini, Hisyam, dkk. 2008. Strategi Pembelajaran Aktif Yogyakarta, Pustaka 